\title{
Immunological Interactions of Tuberculosis with Drugs and Substance Use: A Systematic Review and Update
}

Nathan G Kiboi ${ }^{1^{*}}$, Saraphine N Nebere ${ }^{1}$ and Joseph K Karanja ${ }^{2}$

${ }^{1}$ Department of Biochemistry and Biotechnology, School of Pure and Applied Sciences, Kenyatta University, P. O. Box 43844-00100, Nairobi, Kenya ${ }^{2}$ Department of Zoological Sciences, School of Pure and Applied Sciences, Kenyatta University, P. O. Box 43844-00100, Nairobi, Kenya

\begin{abstract}
Background: Illicit drug and substance use exacerbates tuberculosis (TB) pandemic and complicates management of the disease. Cytokines play a crucial role in TB infection, and recreational drugs of abuse present a confounder in the understanding of immunology of TB. Therefore, this review presents an updated summary describing the immunological link between illicit drug use and TB.

Methods: Information was obtained from previous research findings via Medline search (1990-2015) using the headings tuberculosis, drug interactions, cytokine alterations, prevalence of TB and illicit drug use. In addition, Google scholarly articles and PubMed citations were included in our search.

Discussion: Recreational drug induced immunosuppression hastens TB progression among habitual substance users. Additionally, substance consumption in the context of TB infection alters cytokine production and the ensuing immune responses. In this regard, understanding these interactions forms an integral component in improving clinical outcomes among this cohort.

Conclusions: Drug and substance abuse aggravates TB pandemic and remains a hindrance to effective TB diagnostic and therapeutic strategies. As such, poor adherence to TB treatment and interactions with drugs of abuse remain a hallmark for drug resistance that poses a unique setback in the fight against the world epidemic. In addition, substance consumption promotes derangement in inflammatory responses implicated in TB immunopathogenesis. This review necessitates clear identification on contribution of each substance towards TB predisposition and cytokine dysregulation while adjusting for confounders.
\end{abstract}

Keywords: Tuberculosis; Substance use; Cytokines; Immune alterations; Inflammation

Abbreviations: TB: Tuberculosis; IFN- $\gamma$ : Interferon-Gamma; TNF- $\alpha$ : Tumor Necrosis Factor alpha; IL-10: Interleukin-10; MCP-1: Monocyte Chemoatttractant Protein-1; NK cells: Natural Killer; GMCSF: Granulocyte/Macrophage-Colony Stimulating Factor; CBD: Cannabidiol; ( $\alpha$ 7): Alpha-7 Nicotinic Receptor; (nAChRs): Nicotinic Acetylcholine Receptors; PBMCs: Peripheral Blood Mononuclear Cells

\section{Background}

Tuberculosis (TB) is a disease caused by Mycobacterium tuberculosis affecting the lungs and sometimes disseminates to other body parts [1]. TB is a major global health concern and parallels Human Immunodeficiency Virus (HIV) and diabetes as a leading cause of mortality worldwide [2]. Recent reports estimate a global TB prevalence of 9.0 million with over 1.5 million deaths annually [2]. Likewise, drug and substance use is an emerging health, social and economic problem worldwide. An approximated $5.2 \%$ of the global population aged between 15 and 64 years were reported to be using illicit drugs, with over 183,000 deaths occurring in 2012 [3]. The global burden is estimated at 2 billion alcohol users, 1.3 billion smokers and 185 million drug users mainly dependent on cocaine and heroin [3].

Underlying disease conditions and substance abuse accelerates host inflammatory responses. As such, TB positive illicit drug and substance users suffer heightened systemic inflammation and immune activation as a result of alterations in cytokines expression [4]. Cytokines play a crucial role in the pathogenesis of TB, the outcome of which is mediated by interaction of macrophages, $\mathrm{T}$ cells and the interplay of the signals they produce [5]. For instance, pro-inflammatory cytokines including interferon-gamma (IFN- $\gamma$ ) and tumor necrosis factor alpha (TNF- $\alpha$ ) are involved in granuloma formation that controls mycobacterial replication [6]. In addition, animal model experiments have shown that, mice deficient of IFN- $\gamma$ or IL-12 are highly susceptible to M. tuberculosis $[7,8]$.
On the other hand, anti-inflammatory IL-10 and IL-4 can inhibit immune response to MTB infection and may hence escalate disease progression $[9,10]$. Although IL- 6 is considered a Th- 2 cytokine, it has been associated with protective immunity against Mycobacterium tuberculosis [11].

$\mathrm{CD} 4+\mathrm{T}$ cell count may be employed as a surrogate marker in assessing the functionality and integrity of the cellular immunity component among TB infected population. In light of this, studies have documented that $\mathrm{CD} 4+\mathrm{T}$ cell counts influence both the frequency and severity of active TB disease [12]. Clinical reports indicate that during various microbial infections including Mycobacterium tuberculosis, plasma CD4+ T cells mount crucial adaptive immune responses against these microbial pathogens [13]. However, the exact mechanisms behind this activity are not well understood.

In this review, we compile data on the complexity of the immune response to $\mathrm{TB}$ as well as drug and substance use with a view to improve the understanding of the immunological interaction between illicit substance consumption and TB pathogenesis. We begin by giving an overview on TB immunopathogenesis followed by immunologic derangements caused by various drugs and substance, and finally link

*Corresponding author: Nathan G Kiboi, Department of Biochemistry and Biotechnology, School of Pure and Applied Sciences, Kenyatta University, P. O. Box 43844-00100, Nairobi, Kenya, Tel: +254718145100; E-mail: nathankiboi@ gmail.com

Received January 28, 2016; Accepted March 01, 2016; Published March 06 , 2016

Citation: Kiboi NG, Nebere SN, Karanja JK (2016) Immunological Interactions of Tuberculosis with Drugs and Substance Use: A Systematic Review and Update. J Pulm Respir Med 6: 326. doi:10.4172/2161-105X.1000326

Copyright: $\odot 2016$ Kiboi NG, et al. This is an open-access article distributed under the terms of the Creative Commons Attribution License, which permits unrestricted use, distribution, and reproduction in any medium, provided the original author and source are credited. 
these alterations with TB severity. We conclude with a summary of the relationship between TB and substance use, then give directions for future investigations.

\section{Methods}

Relevant literature was systematically reviewed for the immunological interaction of tuberculosis and substance use through a Medline database search (1990-2015) with restriction to English only articles. The search terms applied included; substance use and Tuberculosis, illicit drugs and $\mathrm{TB}$ interactions, immune alterations during TB and substance use, prevalence of TB and substance use. The common names of frequently used recreational drugs and substances such as cocaine, heroin, opium, bhang, khat and alcohol were also searched. Additionally, relevant Google scholarly articles (Google search), Hinary and PubMed citations matching our search criteria were also critically reviewed for potential significance. Available abstracts of International and National conferences were also included in our review study. Finally standard text books and grey literature material were also examined for essential information before being considered for inclusion in our review.

\section{Results}

Multiple studies were assessed governed by our inclusion and exclusion criteria. This review focused on articles defining cytokine profiles as immunological correlates among Tuberculosis monoinfected drug and substance using population. Hence, articles defining TB in the context of co-morbidities including HIV and Hepatitis failed to meet the threshold for inclusion into the study. Majority of studies identified, employed cross-sectional design; however, case control and prospective cohort studies also featured (Table 1 and Figure 1).

\section{Discussion}

Recreational drug use contributes significantly towards $\mathrm{TB}$ transmission and progression. In addition, drug and substance use modifies cytokine expression and release during TB infection [14]. However, there is insufficiency of information regarding how these harmful substances modulate TB immune responses. Therefore, data in this review provide an insight into mechanisms through which drug and substance use influences TB pathogenesis (Table 2).

\section{Opiates}

Opioid use has been linked to TB acquisition, a fact evidenced by studies describing greater than 100-folds TB incidences among opiate users compared to general population [15]. Experimental studies show that opiates modulate diverse functions of immune cells including phagocytosis, chemotaxis and cytokine expression $[4,16]$, which are crucial for TB elimination. Opiates suppress production of IFN- $\gamma$ and TNF- $\alpha$ which are involved in monocytes and granulocytes recruitment during active TB infection [17]. In addition, opioids down-regulate IL-8 production that is necessary in attracting neutrophils and T cells besides monocytes recruitment $[18,19]$. They exert their effects through specific $\mu$-opioid receptors on immune cells or through regulatory actions on the cells of central nervous system (CNS) [20]. Morphine activates CNS $\mu$-opioid receptors causing suppression of Natural Killer (NK) cell activity in experimental model rats [20], which in turn inhibits IFN- $\gamma$ production in TB [21]. It is noteworthy that variations in expression pattern of these cytokines and chemokines may also be differentially impacted by the type of opioid used.

\section{Cocaine}

Hard drugs, for instance cocaine, may be taken intravenously or through other routes such as inhalation which do not necessarily involve use of injection [22]. On the other hand, respiratory damage arising from habitual use of cocaine makes illicit drug users more vulnerable to infection with pulmonary tuberculosis $[23,24]$. This may be feasibly attributable to the fact that cocaine consumption has been shown to impair alveolar macrophage and immunoregulatory cytokine production which are of vital importance in conferring resistance against tuberculosis disease $[25,26]$. Studies conducted by Roth et al. describe cocaine to cause significant reduction in inducible nitric oxide synthase (iNOS) activity, which results in poor alveolar macrophage antibacterial action [27]. Additionally, cocaine decreases monocyte proinflammatory responses including IFN- $\gamma$, monocyte chemoatttractant protein-1 (mcp-1), TNF- $\alpha$ and granulocyte/macrophage-colony stimulating factor (GM-CSF) which are required in anti $M$. tuberculosis immunity $[26,28]$. Overall, cocaine use attenuates the capacity of monocytes and alveolar macrophages protective mechanisms resulting in failure of response to a mycobacterial challenge with ultimate consequence of failure to arrest TB disease.

\section{Heroin}

Heroin, a morphine derivative is categorized among the routinely used recreational drugs [29]. Its consumption has been associated with heightened risk of $\mathrm{TB}$ acquisition and transmission due to immunosuppressive effects and mode of use [30]. Moreover, studies have documented that heroin uptake modulates cell mediated host inflammatory responses [4], which are key determinants of TB outcome. However, few studies have established combined effects of heroin and cytokine dysregulation in a classical TB setup. Studies conducted in both human and animal model experiments show suppressed IFN- $\gamma$ and TNF- $\alpha$ production following exposure to heroin [31-33], suggesting that heroin down-regulates pro-inflammatory responses which are necessary for host mycobacterial control.

\section{Alcohol}

Alcohol consumption has been related with alterations in innate immune responses. As a result, circulating levels of IFN- $\gamma$, TNF- $\alpha$, IL-12, IL-13, IL-6, monocytes chemo-attractant protein1 (MCP-1) and IL- 1 are observed to be elevated across the time course of alcohol uptake, and the levels have been correlated with serum concentrations of IgG [34,35]. Similarly, interactions between cytokines levels among alcoholics and infectious agents such as TB have been reported [36], whereby repeated alcohol use suppresses TNF- $\alpha$ production which is identified as a mononuclear phagocyte-derived cytokine that has antiTB protective effects $[37,38]$. In retrospect, from the above discussion, it is increasingly clear that circulating levels of inflammatory cytokines produced by monocytes and macrophages is distorted. Thus, these findings imply that, chronic alcohol use causes a dysregulation in cytokine and chemokines expression. Furthermore, alveolar macrophages are recognized as the predominant cells that respond to infectious agents within the lungs [39]. Phagocytic monocytes and macrophage cell function is affected by frequent alcohol use. As such, individuals with alcoholic cirrhosis have shown defects in monocyte phagocytic function $[40,41]$, which plays a critical activity in host immune response against Mycobacterium tuberculosis.

\section{Cannabis sativa (Marijuana)}

The plant Cannabis sativa (Marijuana) contains active constituents termed as Cannabinoids. These active ingredients possess immunomodulatory effects including anti-inflammatory and immunosuppressive characteristics [42,43]. Animal model studies using mice demonstrate that cannabidiol (CBD), a non-psychoactive 
Citation: Kiboi NG, Nebere SN, Karanja JK (2016) Immunological Interactions of Tuberculosis with Drugs and Substance Use: A Systematic Review and Update. J Pulm Respir Med 6: 326. doi:10.4172/2161-105X.1000326

Page 3 of 6

\begin{tabular}{|c|c|c|c|c|c|c|}
\hline Author/year & Title & Year of study & Study country & $\begin{array}{l}\text { Age group studied } \\
\text { (Yrs) }\end{array}$ & Sample size & Study type \\
\hline Story et al. [24] & $\begin{array}{l}\text { Crack cocaine and } \\
\text { infectious tuberculosis }\end{array}$ & 2008 & $\begin{array}{l}\text { London (United } \\
\text { Kingdom) }\end{array}$ & $15-60$ & 970 & Case-control \\
\hline Baldwin et al. [25] & $\begin{array}{l}\text { Marijuana and cocaine } \\
\text { impair alveolar macrophage } \\
\text { function and cytokine } \\
\text { production }\end{array}$ & 1997 & $\begin{array}{c}\text { Los Angeles, } \\
\text { California (USA) }\end{array}$ & $21-49$ & 56 & Case-control \\
\hline Irwin et al. [26] & $\begin{array}{l}\text { Cocaine dependence } \\
\text { and acute cocaine induce } \\
\text { decreases of monocyte } \\
\text { proinflammatory cytokine } \\
\text { expression across the } \\
\text { diurnal period: autonomic } \\
\text { mechanisms }\end{array}$ & 2007 & $\begin{array}{c}\text { Los Angeles, } \\
\text { California (USA) }\end{array}$ & Adults & 55 & $\begin{array}{l}\text { Cross-sectional } \\
\text { survey }\end{array}$ \\
\hline Araos et al. [28] & $\begin{array}{c}\text { Plasma profile of pro- } \\
\text { inflammatory cytokines } \\
\text { and chemokines in cocaine } \\
\text { users under outpatient } \\
\text { treatment: influence of } \\
\text { cocaine symptom severity } \\
\text { and psychiatric co- } \\
\text { morbidity }\end{array}$ & 2014 & Malaga (Spain) & $18-65$ & 147 & Cross-sectional based \\
\hline Honarvar et al. [15] & $\begin{array}{l}\text { Pulmonary and Latent } \\
\text { Tuberculosis Screening } \\
\text { in Opiate Drug Users: An } \\
\text { Essential and Neglected } \\
\text { Approach for Harm- } \\
\text { Reduction Facilities }\end{array}$ & 2013 & Iran & $20-65$ & 300 & Cross-sectional based \\
\hline Leonhardt et al. [23] & $\begin{array}{l}\text { A cluster of tuberculosis } \\
\text { among crack house } \\
\text { contacts in San Mateo } \\
\text { County, California }\end{array}$ & 1994 & California (USA) & Adults & 110 & Prospective survey \\
\hline Kuang et al. [32] & $\begin{array}{c}\text { Changes of the immune } \\
\text { cells, cytokines and growth } \\
\text { hormone in teenager drug } \\
\text { addicts }\end{array}$ & 2007 & China & Teenagers & 43 & Cross-sectional based \\
\hline Weber et al. [22] & $\begin{array}{l}\text { Influence of noninjecting } \\
\text { and injecting drug use on } \\
\text { mortality, retention in the } \\
\text { cohort, and antiretroviral } \\
\text { therapy, in participants in } \\
\text { the Swiss HIV Cohort Study }\end{array}$ & 2015 & Switzerland & Adults & 6529 & Prospective cohort \\
\hline Azarang et al. [33] & $\begin{array}{c}\text { T-helper } 1 \text { and } 2 \text { serum } \\
\text { cytokine assay in chronic } \\
\text { opioid addicts }\end{array}$ & 2007 & Iran & Adults & 20 & Cross-sectional based \\
\hline Awuah et al. [54] & $\begin{array}{l}\text { Dynamics of T-cell IFN- } \mathrm{Y} \\
\text { and miR-29a expression } \\
\text { during active pulmonary } \\
\text { tuberculosis }\end{array}$ & 2014 & Ghana & Adults & 51 & Prospective cohort \\
\hline
\end{tabular}

Note: IFN-ץ: Interferon-gamma; MiR-29a: microRNA 29a; HIV: Human Immunodeficiency Virus.

Table 1: Studies/articles included in the review.

cannabinoid, causes a significant reduction in plasma levels of proinflammatory cytokines such as IFN- $\gamma$ and TNF- $\alpha$ while augmenting secretion of IL-10 and IL-4 levels [44], which play a pivotal role in host immunity against TB disease. Similarly, frequent marijuana use has been shown to impair production of TNF- $\alpha$, granulocyte-macrophage colony stimulating factor (GM-CSF) and IL-6 from alveolar macrophages $[25,27]$. Taken together, these observations indicate that habitual use of marijuana significantly alters normal lung immune responses. However, exact mechanisms describing interactions between cannabinoids and TB immunopathology have not been clearly elucidated $[45,46]$.

\section{Cigarette}

Epidemiological studies have identified cigarette smoking as among the major cofactors increasing susceptibility to respiratory diseases $[47,48]$. However, exact mechanisms through which cigarette smoke predisposes individuals to these infections remains unclear. Cigarette contains nicotine as the addictive component, a stimulant that has been implicated in inhibition of host immune responses [49]. Nicotine impairs IL-10 and TNF- $\alpha$ production through alpha-7 $\left(\alpha_{7}\right)$ nicotinic receptor or nicotinic acetylcholine receptors (nAChRs) which are located on the cells of central nervous system (CNS) as well as immune cells [50,51]. In addition, cigarette smoke reduces both PBMCs and alveolar compartment macrophage IFN- $\gamma$ production [52], which are utilized by the host adaptive mechanism to clear mycobacterial infection [53,54]. Experimental animal models using murine mice have shown nicotine to inhibit IL-6, IL-12 and TNF- $\alpha$ production by alveolar macrophages through nAChRs [55]. In conclusion, there is substantial proof that nicotine and other cigarette derivatives attenuate cytokine responses which are essential for conferring protective immunity against pulmonary infections such as Mycobacterium tuberculosis.

\section{Khat (Catha edulis)}

Khat chewing is a common practice especially in Eastern Africa and 


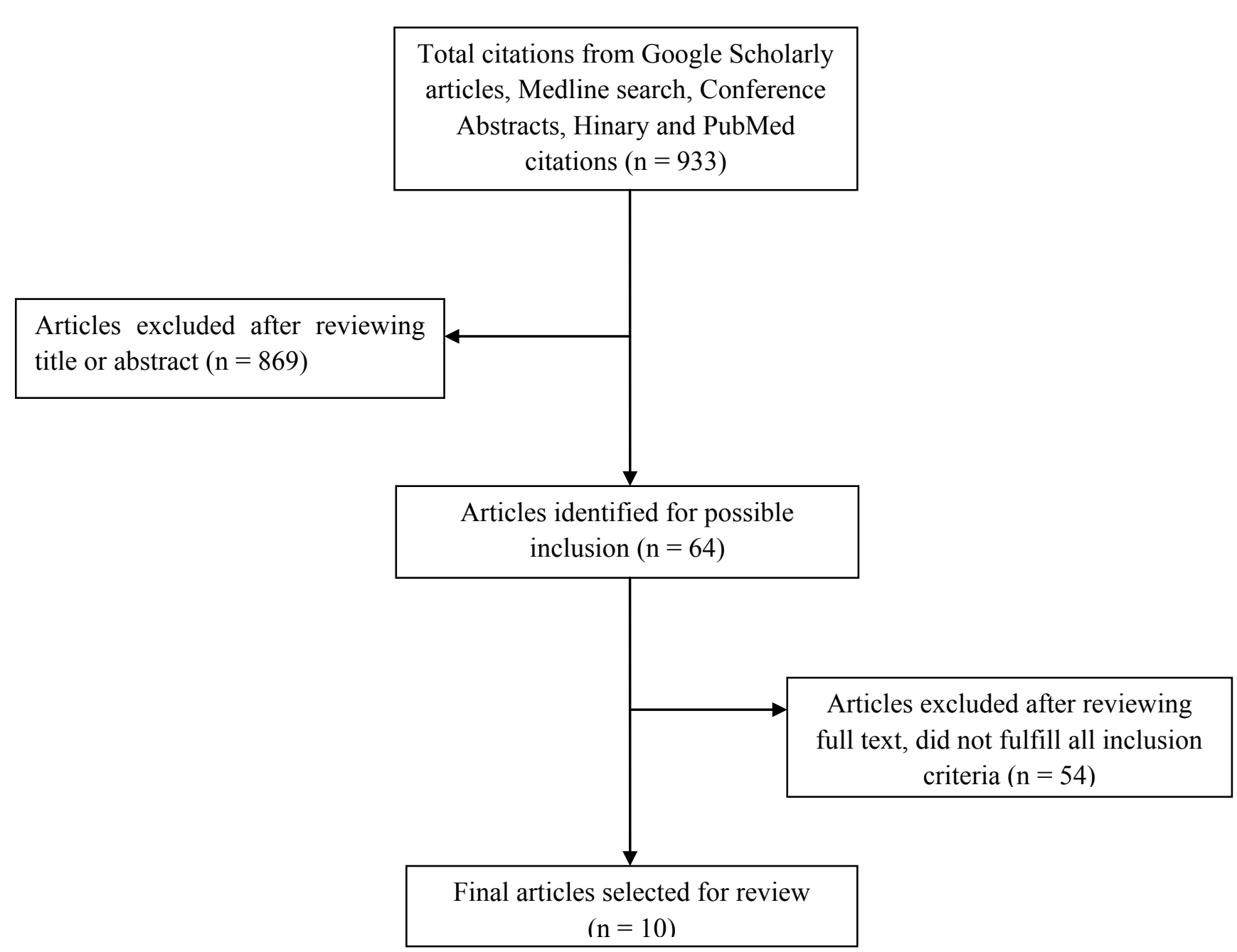

Figure 1: Search strategy and results.

\begin{tabular}{|l|l|}
\hline Drugs & Substances \\
\hline Opioids & Alcohol \\
\hline Cocaine & Cigarettes \\
\hline Heroin & Cannabis sativa (Marijuana) \\
\hline & Catha edulis (Khat) \\
\hline
\end{tabular}

Table 2: Classification of drugs and substances of abuse [3].

Middle East regions [56]. Leaves of khat are known to comprise of two alkaloids namely, cathinone and cathine which possess amphetaminelike features that cause psycho-stimulation manifesting as euphoria and excitement $[57,58]$. Habitual khat chewing has been linked with increased risk of oral diseases. As a result, various studies show that prolonged use of khat promotes pathological alterations in human buccal mucosa which triggers an abnormal differentiation of the buccal epithelium [59]. Consequently, additional studies suggest that this abnormal buccal epithelial cell differentiation is associated with high incidence of oral cancer $[60,61]$. However, there is limited information on the effects of khat on immune cells. Khat-treated PBMCs have shown reduced expression of inflammatory cytokines including TNF- $\alpha$ and IL- 6 while production of IFN- $\gamma$, IL- 2 and IL-10 is significantly increased [62]. This suggests that khat interferes with kinetics of cytokine expression from immune effector cells, which impacts negatively on the host immune surveillance system. On the other hand, regular khat use escalates the risk of acquiring Mycobacterium tuberculosis infection through immune modulation of lung resident macrophages [63] that offer first line defense against pulmonary TB [64].

\section{Conclusions and Future Directions}

Immune factors and their influence on TB disease among drug and substance users remains poorly defined. However, there is adequate evidence linking drug and harmful substance use to modification of inflammatory responses, which are crucial in TB immunopathology. Therefore, this review highlights the need for clinicians and other healthcare providers to assess the impact of recreational drug and substance use among TB patients for effective therapeutic strategies.

\section{Competing Interests}

The authors have declared no competing interests.

\section{Authors' Contributions}

All authors contributed equally in drafting, review of article and revising the manuscript. Final version of the manuscript was approved by all authors.

\section{Acknowledgments}

The authors thank Kenyatta University library for facilitating space and accessibility to online databases used to gather relevant information for this review. 
Citation: Kiboi NG, Nebere SN, Karanja JK (2016) Immunological Interactions of Tuberculosis with Drugs and Substance Use: A Systematic Review and Update. J Pulm Respir Med 6: 326. doi:10.4172/2161-105X.1000326

This work received no specific grant from any funding agency whatsoever.

\section{References}

1. Knechel NA (2009) Tuberculosis: pathophysiology, clinical features, and diagnosis. Crit Care Nurse 29: 34-43.

2. Organization WH (2015) Global tuberculosis report 2015.

3. UNODC (2013) World Drug Report 2013. United Nations Publication Vienna.

4. Roy S, Ninkovic J, Banerjee S, Charboneau RG, Das S, et al. (2011) Opioid drug abuse and modulation of immune function: consequences in the susceptibility to opportunistic infections. J Neuroimmune Pharmacol 6: 442-465.

5. Munk ME, Emoto M (1995) Functions of T-cell subsets and cytokines in mycobacterial infections. Eur Respir J Suppl 20: 668s-675s.

6. Diedrich CR, Flynn JL (2011) HIV-1/mycobacterium tuberculosis coinfection immunology: how does HIV-1 exacerbate tuberculosis? Infect Immun 79: 14071417.

7. Flynn JL, Goldstein MM, Chan J, Triebold KJ, Pfeffer K, et al. (1995) Tumo necrosis factor-a is required in the protective immune response against Mycobacterium tuberculosis in mice. Immunity 2: 561-572.

8. Cooper AM, Magram J, Ferrante J, Orme IM (1997) Interleukin 12 (IL-12) is crucial to the development of protective immunity in mice intravenously infected with mycobacterium tuberculosis. J Exp Med 186: 39-45.

9. Redford PS, Murray PJ, O'Garra A (2011) The role of IL-10 in immune regulation during M. tuberculosis infection. Mucosal Immunol 4: 261-270.

10. Skolimowska KH, Rangaka MX, Meintjes G, Pepper DJ, Seldon R, et al. (2012) Altered ratio of IFN-y/LL-10 in patients with drug resistant Mycobacterium tuberculosis and HIV-tuberculosis immune reconstitution inflammatory syndrome. PLoS One 7: e46481.

11. Ladel CH, Blum C, Dreher A, Reifenberg K, Kopf M, et al. (1997) Lethal tuberculosis in interleukin-6-deficient mutant mice. Infect Immun 65: 48434849 .

12. Jones BE, Oo MM, Taikwel EK, Qian D, Kumar A, et al. (1997) CD4 cell counts in human immunodeficiency virus-negative patients with tuberculosis. Clin Infect Dis 24: 988-991.

13. Gallegos AM, Pamer EG, Glickman MS (2008) Delayed protection by ESAT6 -specific effector CD4+ T cells after airborne M. tuberculosis infection. J Exp Med 205: 2359-2368.

14. Friedman H, Newton C, Klein TW (2003) Microbial infections, immunomodulation, and drugs of abuse. Clin Microbiol Rev 16: 209-219.

15. Honarvar B, Lankarani KB, Odoomi N, Roudgari A, Moghadami M, et al. (2013) Pulmonary and latent tuberculosis screening in opiate drug users: an essential and neglected approach for harm-reduction facilities. J Addict Med 7: 230-235.

16. Friedman H, Pross S, Klein TW (2006) Addictive drugs and their relationship with infectious diseases. FEMS Immunol Med Microbiol 47: 330-342.

17. Stefano GB, Kream RM (2010) Opioid peptides and opiate alkaloids in immunoregulatory processes. Arch Med Sci 6: 456-460.

18. Mukaida N, Harada A, Matsushima K (1998) Interleukin-8 (IL-8) and monocyte chemotactic and activating factor (MCAF/MCP-1), chemokines essentially involved in inflammatory and immune reactions. Cytokine Growth Factor Rev 9: 9-23.

19. Bastami S, Norling C, Trinks C, Holmlund B, Walz TM, et al. (2013) Inhibitory effect of opiates on LPS mediated release of TNF and IL-8. Acta Oncol 52 1022-1033.

20. Saurer TB, Carrigan KA, ljames SG, Lysle DT (2006) Suppression of natura killer cell activity by morphine is mediated by the nucleus accumbens shell. $J$ Neuroimmunol 173: 3-11.

21. Portevin D, Via LE, Eum S, Young D (2012) Natural killer cells are recruited during pulmonary tuberculosis and their ex vivo responses to mycobacteria vary between healthy human donors in association with KIR haplotype. Cell Microbiol 14: 1734-1744.

22. Weber R, Huber M, Battegay M, Stähelin C, Castro Batanjer E, et al. (2015) Influence of noninjecting and injecting drug use on mortality, retention in the cohort, and antiretroviral therapy, in participants in the Swiss HIV Cohort Study. HIV Med 16: 137-151.
23. Leonhardt KK, Gentile F, Gilbert BP, Aiken M (1994) A cluster of tuberculosis among crack house contacts in San Mateo County, California. Am J Public Health 84: 1834-1836.

24. Story A, Bothamley G, Hayward A (2008) Crack cocaine and infectious tuberculosis. Emerg Infect Dis 14: 1466-1469.

25. Baldwin GC, Tashkin DP, Buckley DM, Park AN, Dubinett SM, et al. (1997) Marijuana and cocaine impair alveolar macrophage function and cytokine production. Am J Respir Crit Care Med 156: 1606-1613.

26. Irwin MR, Olmos L, Wang M, Valladares EM, Motivala SJ, et al. (2007) Cocaine dependence and acute cocaine induce decreases of monocyte proinflammatory cytokine expression across the diurnal period: autonomic mechanisms. J Pharmacol Exp Ther 320: 507-515.

27. Roth MD, Whittaker K, Salehi K, Tashkin DP, Baldwin GC (2004) Mechanisms for impaired effector function in alveolar macrophages from marijuana and cocaine smokers. J Neuroimmunol 147: 82-86.

28. Araos P, Pedraz M, Serrano A, Lucena M, Barrios V, et al. (2015) Plasma profile of pro-inflammatory cytokines and chemokines in cocaine users under outpatient treatment: influence of cocaine symptom severity and psychiatric co-morbidity. Addict Biol 20: 756-772.

29. Uchtenhagen AA (2011) Heroin maintenance treatment: from idea to research to practice. Drug Alcohol Rev 30: 130-137.

30. Deiss RG, Rodwell TC, Garfein RS (2009) Tuberculosis and illicit drug use: review and update. Clin Infect Dis 48: 72-82.

31. Lorenzo P, Portolés A Jr, Beneit JV, Ronda E, Portolés A (1987) Physical dependence to morphine diminishes the interferon response in mice. Immunopharmacology 14: 93-99.

32. Kuang YM, Zhu YC, Kuang Y, Sun Y, Hua C, et al. (2007) [Changes of the immune cells, cytokines and growth hormone in teenager drug addicts]. Xi Bao Yu Fen Zi Mian Yi Xue Za Zhi 23: 821-823

33. Azarang A, Mahmoodi M, Rajabalian S, Shekari MA, Nosratabadi J, et al. (2007) T-helper 1 and 2 serum cytokine assay in chronic opioid addicts. Eur Cytokine Netw 18: 210-214

34. Khoruts A, Stahnke L, McClain CJ, Logan G, Allen Jl (1991) Circulating tumor necrosis factor, interleukin-1 and interleukin-6 concentrations in chronic alcoholic patients. Hepatology 13: 267-276.

35. He J, Crews FT (2008) Increased MCP-1 and microglia in various regions of the human alcoholic brain. Exp Neurol 210: 349-358.

36. Molina PE, McNurlan M, Rathmacher J, Lang CH, Zambell KL, et al. (2006) Chronic alcohol accentuates nutritional, metabolic, and immune alterations during asymptomatic simian immunodeficiency virus infection. Alcohol Clin Exp Res 30: 2065-2078.

37. Verma BK, Fogarasi M, Szabo G (1993) Down-regulation of tumor necrosis factor alpha activity by acute ethanol treatment in human peripheral blood monocytes. J Clin Immunol 13: 8-22.

38. Nelson S, Mason C, Bagby G, Summer W (1995) Alcohol, tumor necrosis factor, and tuberculosis. Alcohol Clin Exp Res 19: 17-24.

39. Gutierrez MG, Master SS, Singh SB, Taylor GA, Colombo MI, et al. (2004) Autophagy is a defense mechanism inhibiting BCG and Mycobacterium tuberculosis survival in infected macrophages. Cell 119: 753-766.

40. Silvain C, Patry C, Launay P, Lehuen A, Monteiro RC (1995) Altered expression of monocyte IgA Fc receptors is associated with defective endocytosis in patients with alcoholic cirrhosis. Potential role for IFN-gamma. J Immunol 155 1606-1618.

41. Szabo G (1999) Consequences of alcohol consumption on host defence. Alcohol Alcohol 34: 830-841.

42. Klein TW, Newton CA, Nakachi N, Friedman H (2000) Delta 9-tetrahydrocannabinol treatment suppresses immunity and early IF N-gamma, IL-1, and IL-12 receptor 32 responses to Legionella pneumophila infection. J Immunol 164: 6461-6466.

43. Mbvundula EC, Rainsford KD, Bunning RA (2004) Cannabinoids in pain and inflammation. Inflammopharmacology 12: 99-114.

44. Weiss L, Zeira M, Reich S, Har-Noy M, Mechoulam R, et al. (2006) Cannabidio lowers incidence of diabetes in non-obese diabetic mice. Autoimmunity 39 : 143-151. 
Citation: Kiboi NG, Nebere SN, Karanja JK (2016) Immunological Interactions of Tuberculosis with Drugs and Substance Use: A Systematic Review and Update. J Pulm Respir Med 6: 326. doi:10.4172/2161-105X.1000326

Page 6 of 6

45. Friedman H, Klein TW, Newton C, Daaka Y (1995) Marijuana, receptors and immunomodulation. Adv Exp Med Biol 373: 103-113.

46. Tashkin DP (2013) Effects of marijuana smoking on the lung. Ann Am Thorac Soc 10: 239-247.

47. Almirall J, Bolíbar I, Balanzó X, González CA (1999) Risk factors for communityacquired pneumonia in adults: a population-based case-control study. Eur Respir J 13: 349-355

48. Feng Y, Kong Y, Barnes PF, Huang FF, Klucar P, et al. (2011) Exposure to cigarette smoke inhibits the pulmonary $\mathrm{T}$-cell response to influenza virus and Mycobacterium tuberculosis. Infect Immun 79: 229-237.

49. Sopori M (2002) Effects of cigarette smoke on the immune system. Nat Rev Immunol 2: 372-377.

50. Wang H, Yu M, Ochani M, Amella CA, Tanovic M, et al. (2003) Nicotinic acetylcholine receptor alpha7 subunit is an essential regulator of inflammation. Nature 421: 384-388.

51. Sternberg EM (2006) Neural regulation of innate immunity: a coordinated nonspecific host response to pathogens. Nat Rev Immunol 6: 318-328.

52. van Zyl-Smit RN, Binder A, Meldau R, Semple PL, Evans A, et al. (2014) Cigarette smoke impairs cytokine responses and BCG containment in alveolar macrophages. Thorax 69: 363-370.

53. Ribeiro-Rodrigues R, Resende Co T, Johnson JL, Ribeiro F, Palaci M, et al. (2002) Sputum cytokine levels in patients with pulmonary tuberculosis as early markers of mycobacterial clearance. Clin Diagn Lab Immunol 9: 818-823.

54. Afum-Adjei Awuah A, Ueberberg B, Owusu-Dabo E, Frempong M, Jacobsen M (2014) Dynamics of T-cell IFN-y and miR-29a expression during active pulmonary tuberculosis. Int Immunol 26: 579-582.
55. Matsunaga K, Klein TW, Friedman H, Yamamoto Y (2001) Involvement of nicotinic acetylcholine receptors in suppression of antimicrobial activity and cytokine responses of alveolar macrophages to Legionella pneumophila infection by nicotine. J Immunol 167: 6518-6524.

56. Aden A, Dimba EA, Ndolo UM, Chindia ML (2006) Socio-economic effects of khat chewing in north eastern Kenya. East Afr Med J 83: 69-73.

57. Kalix P (1992) Cathinone, a natural amphetamine. Pharmacol Toxicol 70: 7786.

58. Patel NB (2000) Mechanism of action of cathinone: the active ingredient of khat (Catha edulis). East Afr Med J 77: 329-332.

59. Lukandu OM, Neppelberg E, Vintermyr OK, Johannessen AC, Costea DE (2010) Khat alters the phenotype of in vitro-reconstructed human oral mucosa. J Dent Res 89: 270-275.

60. Soufi HE, Kameswaran M, Malatani T (1991) Khat and oral cancer. J Laryngo Otol 105: 643-645

61. Warnakulasuriya S (2009) Causes of oral cancer--an appraisal of controversies. Br Dent J 207: 471-475.

62. Murdoch C, Aziz HA, Fang HY, Jezan H, Musaid R, et al. (2011) Khat (Catha edulis) alters the phenotype and anti-microbial activity of peripheral blood mononuclear cells. J Ethnopharmacol 138: 780-787.

63. Alvi A, Rizwan M, Sunosi RA, Bin Ali Jerah A (2014) Does khat chewing increases the risk of Mycobacterium tuberculosis infection by macrophage immune modulation? Med Hypotheses 82: 667-669.

64. Cooper AM (2009) Cell-mediated immune responses in tuberculosis. Annu Rev Immunol 27: 393-422. 